\title{
Experimental evaluation of stone masonry walls with lime based mortar under vertical loads
}

\author{
M. Abdel-Mooty ${ }^{1}$, A. Al Attar ${ }^{2}$ \& M. El Tahawy ${ }^{2}$ \\ ${ }^{I}$ Department of Construction and Architectural Engineering, \\ The American University in Cairo, Egypt \\ ${ }^{2}$ Structural Eng. Dept., Faculty of Engineering, Cairo University, Egypt
}

\begin{abstract}
Stone masonry walls of natural limestone blocks and lime based mortar similar to those used in ancient structures are tested under vertical loading and presented in this paper. The research program includes testing of wall components as well as wall assemblages under vertical loads to study the different factors affecting the wall strength, ductility and load-deformation behaviour up to failure. The considered factors cover: natural limestone block strength, lime based mortar strength, the relative dimensions and composition of the wall assembly as well as the thickness of mortar joints. Two types of natural stones of different strength, several mixes of lime based mortar with different strengths, and different systems and composition of wall models are tested in this research. Twelve wall specimens are considered including six single leaf walls, five double leaf walls and one cavity wall with shear key. It was found that the type and strength of mortar has significant effect on the overall wall behaviour. Also of paramount importance is the effect of the thickness of mortar joints on the wall ductility. The stress distribution within the wall component was recorded during wall testing to failure for further analysis.

Keywords: limestone masonry wall, lime based mortar, wall ductility, testing.
\end{abstract}

\section{Introduction}

Structural restoration of historical architecture involves in many cases strengthening and rebuilding of stone masonry wall at designated locations to restore the integrity of the monument. This restoration effort must be made with 
minimum intervention and must be compatible with the old material of the wall, basically limestone blocks and lime based mortar [1, 2].

Limestone masonry with lime based mortar is a relatively complex system whose behaviour in general is nonlinear [3-5]. The wall structural performance under load and strength depends on many factors such as the nature of stone, dimensions of the single block, arrangement in the structure and also the type of mortar that is used to connect the stones. Reliable numerical modelling of the wall behaviour requires accurate determination of the mechanical properties of its constituencies and detailed calibration of the developed models against comprehensive experimental test results [6-8]. This research tries to obtain a reliable evaluation from an experimental test on masonry wall components and wall system.

The structural behaviour of the stone masonry wall depends very much on the mechanical characteristics of its components, namely the stone and the mortar. Furthermore, the structure of the wall such as single leaf, double-leaf of cavity wall with rubble infill significantly affects its load capacity and failure mode. The above factors in addition to the thickness of the mortar joints are investigated in this research.

The materials used in this study are natural lime stone blocks cut from local regions in Egypt. Three types of lime based mortars are used in this research. The first type consists of sand, lime and water. The second type consists of lime, sand, water and small amount of white cement to give strength to the mortar. The third type consists of lime, sand, water, small amount of white cement and small amount of stone rubbles. These three types of mortar are similar to that used in ancient constructions. The amount of white cement was added to give higher strength to the mortar. Several mortar mixes are tested in this study. The mortar mixes are classified as weak mortar (type one), strong mortar (type two) and strong mortar with stone rubbles (type three).

\section{Experimental program and test set-up}

The test program aims at evaluating the effect of different parameters on the performance of limestone masonry walls with lime based mortar under in-plane vertical loads up to failure (Table 1). The tested parameters are:

1. Wall structure where three different wall systems are used (Figure 1)

a. Single wall model of thickness $120 \mathrm{~mm}$

b. Double wall model of thickness $250 \mathrm{~mm}$

c. Cavity wall model made of external leaf stone blocks of thickness $120 \mathrm{~mm}$ and lime based rubble infill of thickness 210 $\mathrm{mm}$. Thus, the overall thickness of the wall is $450 \mathrm{~mm}$.

2. Lime based mortar strength where two types of mortars are used:

a. Weak lime mortar

b. Strong lime mortar with white cement of $5 \%$ of lime weight

3. Three different thickness of horizontal and vertical lime based mortar joints 15,10 , and $5 \mathrm{~mm}$. 
Table 1: $\quad$ Tested wall specimens dimensions and parameters.

\begin{tabular}{|c|c|c|c|c|c|c|}
\hline \multirow{4}{*}{ Wall Type } & $\begin{array}{c}\text { Wall } \\
\text { No. }\end{array}$ & $\begin{array}{c}\text { Wall } \\
\text { Length } \\
\text { Mm }\end{array}$ & $\begin{array}{c}\text { Wall } \\
\text { Height } \\
\text { mm }\end{array}$ & $\begin{array}{c}\text { Wall } \\
\text { Thickness } \\
\text { mm }\end{array}$ & $\begin{array}{c}\text { Mortar } \\
\text { Thickness } \\
\text { mm }\end{array}$ & $\begin{array}{c}\text { Mortar } \\
\text { Type }\end{array}$ \\
\hline \multirow{4}{*}{$\begin{array}{c}\text { Single wall } \\
\text { model }\end{array}$} & W1 & 780 & 1050 & 120 & 15 & Weak \\
\cline { 2 - 7 } & W2 & 780 & 1050 & 120 & 15 & Strong \\
\cline { 2 - 7 } & W4 & 770 & 1000 & 120 & 10 & Weak \\
\cline { 2 - 7 } & W5 & 760 & 950 & 120 & 5 & Weak \\
\cline { 2 - 7 } & W6 & 760 & 950 & 120 & 5 & Strong \\
\hline \multirow{4}{*}{$\begin{array}{c}\text { Double wall } \\
\text { model }\end{array}$} & W7 & 780 & 1050 & 250 & 15 & Strong \\
\cline { 2 - 7 } & W8 & 770 & 1000 & 250 & 10 & Weak \\
\cline { 2 - 7 } & W10 & 770 & 1000 & 250 & 10 & Strong \\
\cline { 2 - 7 } & W11 & 760 & 950 & 250 & 5 & Strong \\
\hline Cavity wall & W12 & 780 & 1050 & 450 & 15 & Strong \\
\hline
\end{tabular}

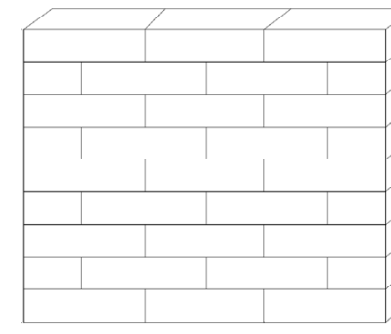

Single wall model

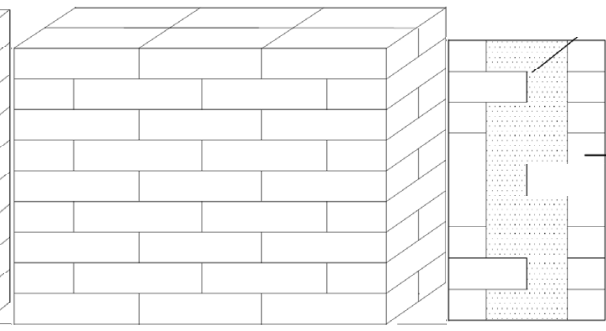

Double wall Model
Cavity wall with infill

Figure 1: Tested models of wall specimens.

The effect of the above parameters on the performance of the limestone masonry walls is evaluated my examining the in-plane compressive failure load, load deformation relationship to failure, wall ductility, and cracking pattern and wall integrity at failure load.

Limestone blocks of dimensions $250 \times 120 \times 100 \mathrm{~mm}$ cut from Mokattam mountain quarry in Egypt are used in this research. The mechanical properties of the limestone block are experimentally determined. Four blocks are tested under compression yielding average compressive strength of $30.9 \mathrm{~N} / \mathrm{mm}^{2}$. The average of indirect splitting tension test of three specimens is used to determine the tensile strength of the used limestone blocks as $1.3 \mathrm{~N} / \mathrm{mm}^{2}$.

In a previous comprehensive study by the first author, different types of lime based mortar for restoration of historical building were studied in detailed where the advantages and limitations were identified [9]. In this paper, three types of 
lime based mortar are developed and tested. Those are nominated as weak mortar of $25 \%$ lime and $75 \%$ sand; strong mortar of $25 \%$ lime, $5 \%$ white cement and $70 \%$ sand, and strong mortar with stone rubble of $25 \%$ lime, $5 \%$ white cement, $5 \%$ limestone rubble, and $65 \%$ sand. Forty four mortar cubes and six mortar cylinders were tested for the different mixes. The average 28 days compressive strength were experimentally identified as $0.14 \mathrm{~N} / \mathrm{mm}^{2}$ for weak mortar, 0.6 $\mathrm{N} / \mathrm{mm}^{2}$ for strong mortar and $0.77 \mathrm{~N} / \mathrm{mm}^{2}$ for strong mortar with rubbles.

All specimens were built on reinforced concrete base beam to facilitate movement and placement of the specimens on the test frame after 28 days from construction. To ensure even distribution of compression loads on the top of wall models, a system of steel beams were used to distribute the point load of the actuator evenly on the wall (Figure 2 and 3). The capacity of the test frame is $5000 \mathrm{kN}$ connected to a load cell of the same capacity. The instrumentation attached to the specimens also included LVDT to measure the vertical displacement of the wall; LVDT to measure the out of plane movement of the wall during testing, and strain gauges attached to the face of the stone blocks to measure vertical and horizontal strain (Figure 4). All specimens were loaded by increasing in-plane vertical load up to failure. The loads, vertical deformation, lateral deformation and strains are recorded during testing using data acquisition system for further analysis.

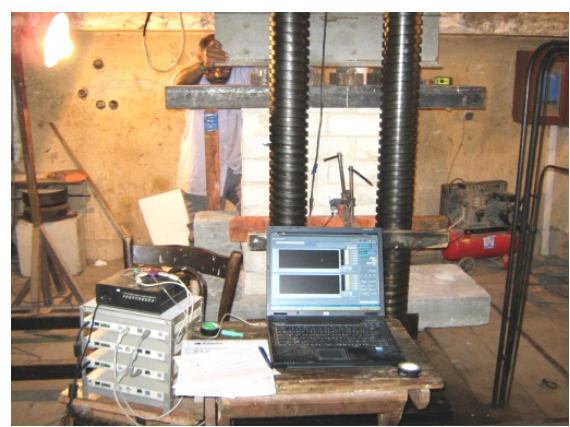

Figure 2: Experimental set-up.

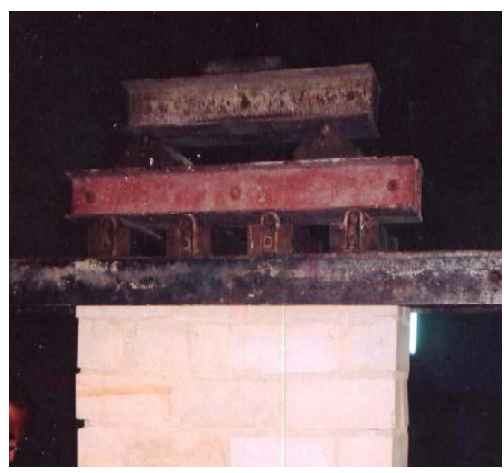

Figure 3: Loading beam on wall top. 


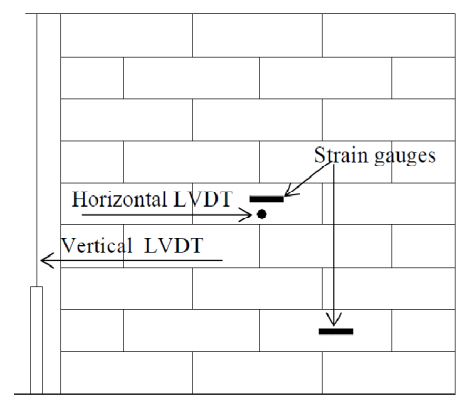

Figure 4: Instrumentation layout.

\section{Experimental results}

The wall specimens were continuously loaded up to failure, and the data was recorded using data acquisition system connected to personal computer. In all tested specimens of single leaf wall models W1 to W6, it was observed that the initial cracking started from stone above the vertical joint and extended up to the top of the wall as shown in Figures 5. The average stress on the wall section was calculated by dividing the applied load by the gross cross sectional area of the wall. Figures 6-11 shows the variation of average stress with the average strain up to failure for single leaf wall models. The values of failure loads and the corresponding stresses for all wall is summarized in Table 2.

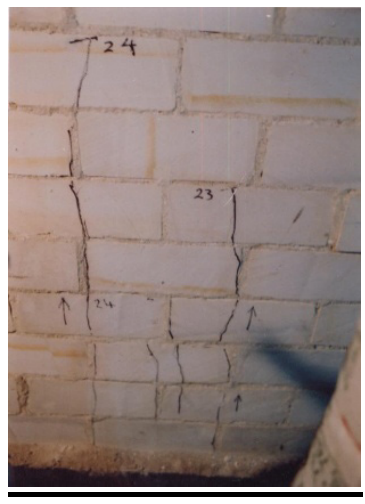

Wall W1

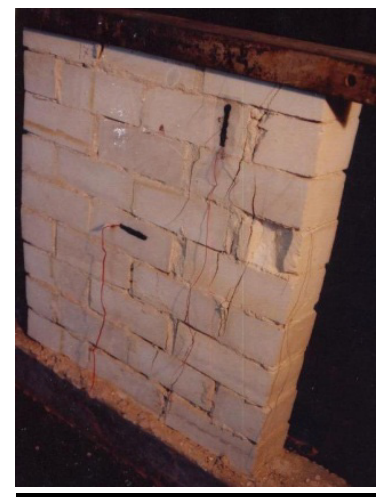

Wall W2

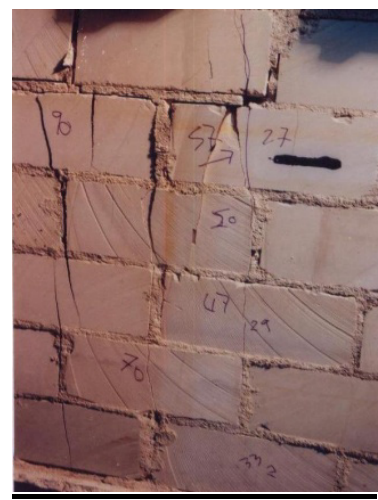

Wall W3

Figure 5: Crack pattern at failure of single leaf wall structure.

Double leaf wall models were tested under increasing in-plane compressive load to failure. In almost all walls, cracking due to splitting of stone resulting from transversal stresses due to mortar squeezing started at the bed joint at the bottom of the wall and propagated upward. Eventually the wall failed due to splitting failure of the two faces of the wall as shown in Figure 12. Figures 13 
and 14 display the variation of the average compressive stress with the average strain up to failure for wall models $\mathrm{W} 7$ and $\mathrm{W} 11$ respectively. The results of the test for walls W7 to W11 are shown in Table 2.

Table 2: $\quad$ Summary of test results.

\begin{tabular}{|c|c|c|c|c|c|}
\hline Wall Type & $\begin{array}{l}\text { Wall } \\
\text { No. }\end{array}$ & $\begin{array}{c}\text { Mortar } \\
\text { type }\end{array}$ & $\begin{array}{c}\text { Mortar } \\
\text { joint } \\
\text { thickness } \\
\text { mm } \\
\end{array}$ & $\begin{array}{c}\text { Failure } \\
\text { load } \\
(\mathbf{k N})\end{array}$ & $\begin{array}{c}\text { Stress at } \\
\text { failure } \\
\mathbf{N} / \mathbf{m m}^{2}\end{array}$ \\
\hline \multirow{6}{*}{ Single wall model } & W1 & Weak & 15 & 240 & 2.6 \\
\hline & W2 & Strong & 15 & 590 & 6.3 \\
\hline & W3 & Weak & 10 & 360 & 3.9 \\
\hline & W4 & Strong & 10 & 900 & 9.7 \\
\hline & W5 & Weak & 5 & 350 & 3.8 \\
\hline & W6 & Strong & 5 & 456 & 5.0 \\
\hline \multirow{5}{*}{ Double wall model } & W7 & Strong & 15 & 918 & 4.7 \\
\hline & W8 & Weak & 10 & 850 & 4.4 \\
\hline & W9 & Strong & 10 & 970 & 5.0 \\
\hline & W10 & Weak & 5 & 430 & 2.3 \\
\hline & W11 & Strong & 5 & 890 & 4.7 \\
\hline Cavity wall & W12 & Strong & 15 & 600 & 1.7 \\
\hline
\end{tabular}

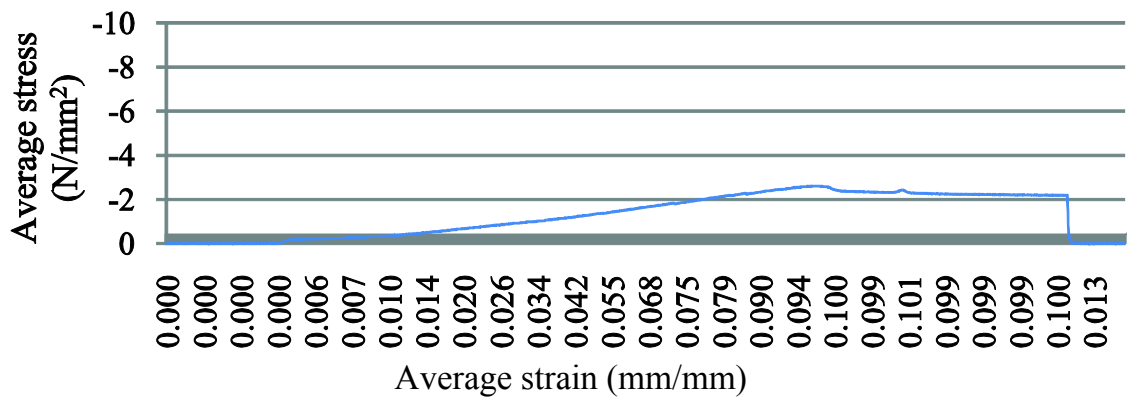

Figure 6: Stress-strain relationship of specimen $\mathrm{W} 1$ to failure.

Wall W12 is a cavity wall (450 mm thickness) build with lime stone blocks $120 \mathrm{~mm}$ thick on the outer faces with $15 \mathrm{~mm}$ thick mortar joints. The wall faces are bonded together with $210 \mathrm{~mm}$ thick strong mortar with limestone rubble as infill between the wall faces. The specimen was continuously loaded up to failure load at $600 \mathrm{kN}$. The cracking started from the two side faces of the wall, and propagates upward. The mode of failure was mainly due to separation of the two faces of the cavity wall as shown in Figure 15. Cracks propagated around the stones instead of through stone blocks due to the weakness of the thick mortar infill compared to the stone blocks. 


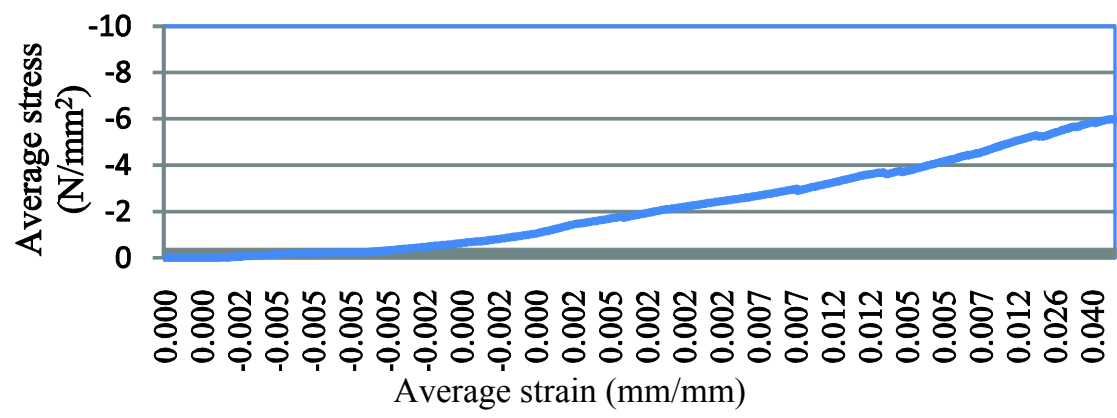

Figure 7: Stress-strain relationship of specimen W2 to failure.

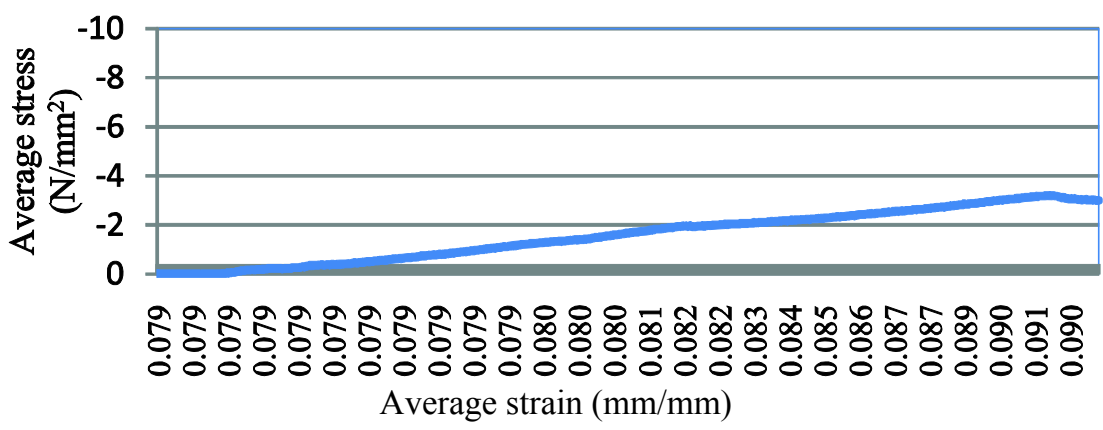

Figure 8: $\quad$ Stress-strain relationship of specimen W3 to failure.

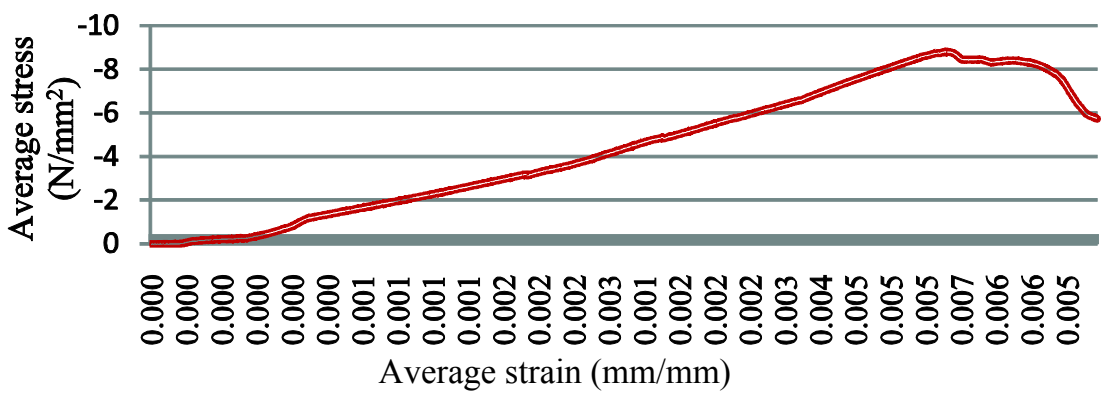

Figure 9: $\quad$ Stress-strain relationship of specimen W4 to failure.

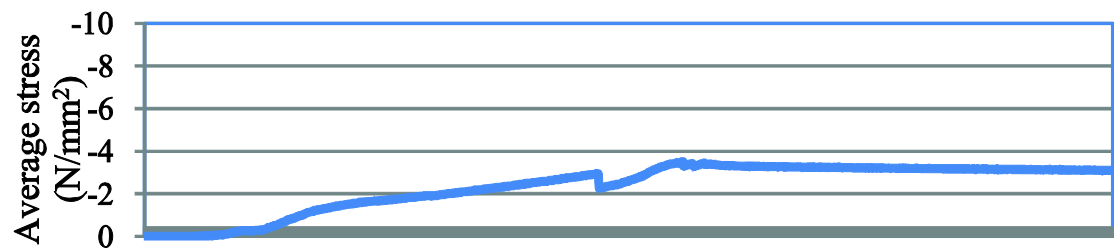

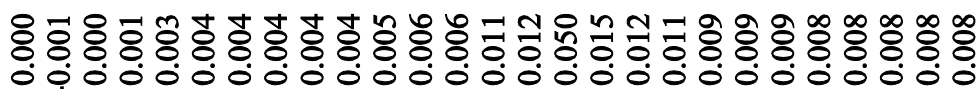 Average strain $(\mathrm{mm} / \mathrm{mm})$}

Figure 10: $\quad$ Stress-strain relationship of specimen W5 to failure. 


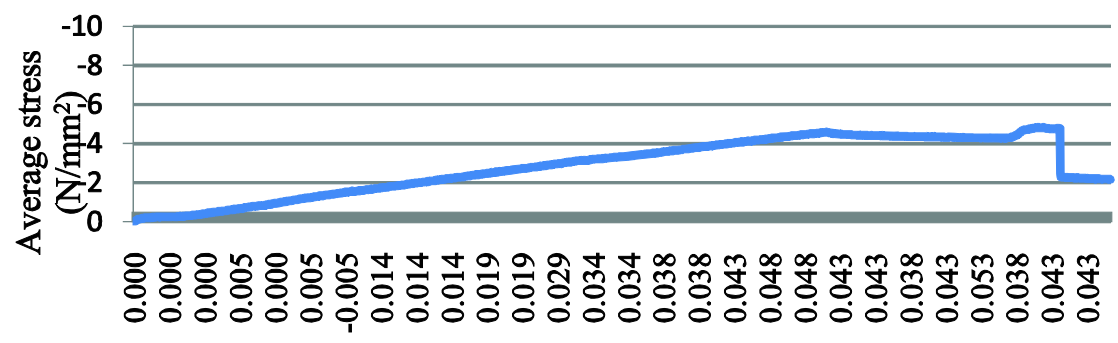

Average strain $(\mathrm{mm} / \mathrm{mm})$

Figure 11: Stress-strain relationship of specimen W6 to failure.

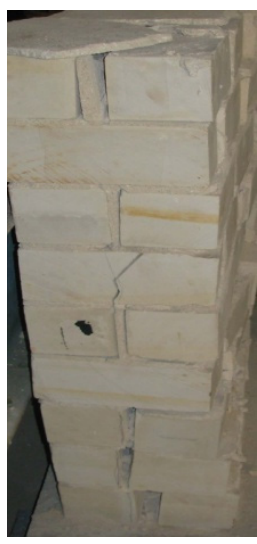

Wall W7

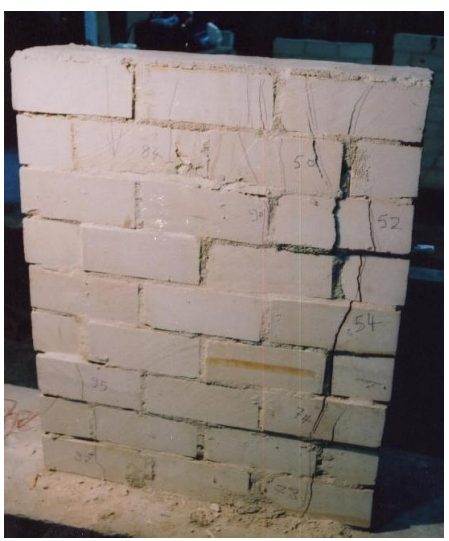

Wall W9

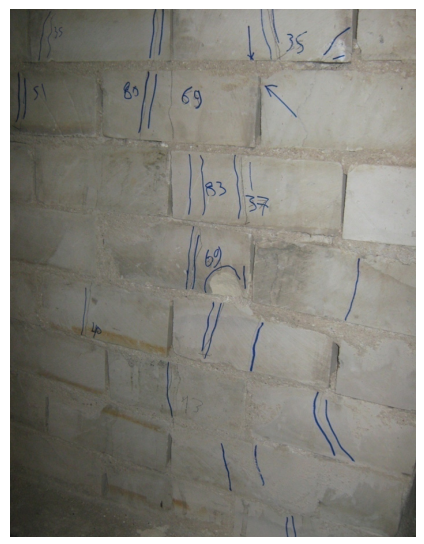

Wall W11

Figure 12: Typical failure of double leaf stone masonry wall specimen.

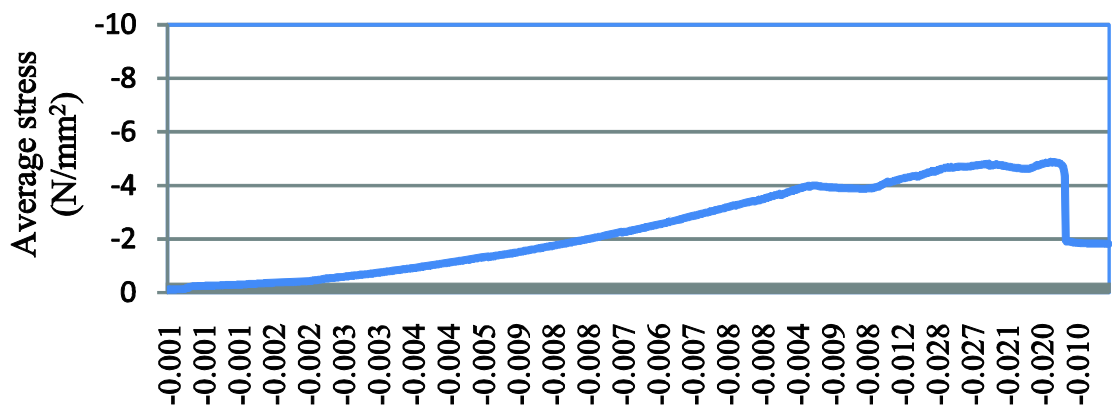

Average strain $(\mathrm{mm} / \mathrm{mm})$

Figure 13: Stress-strain relationship of specimen W7 to failure. 


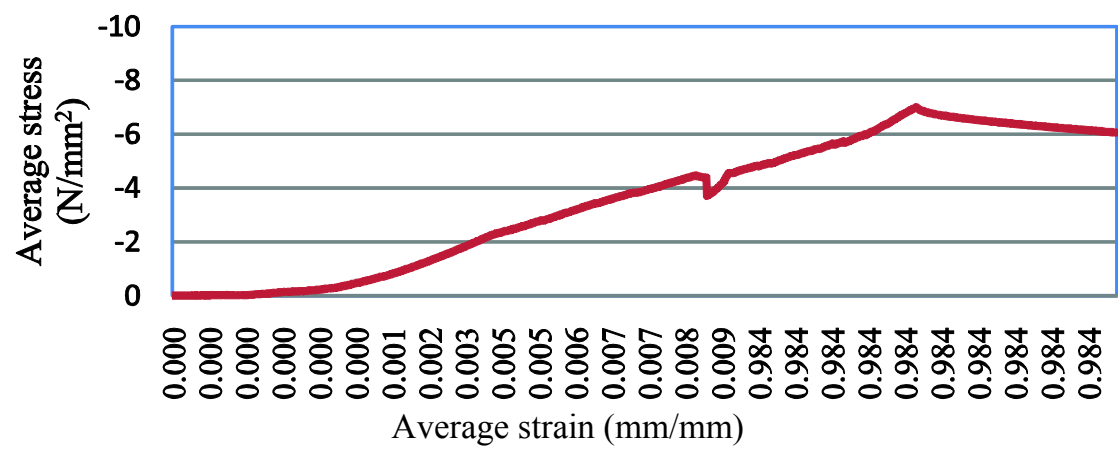

Figure 14: Stress-strain relationship of specimen W11 to failure.

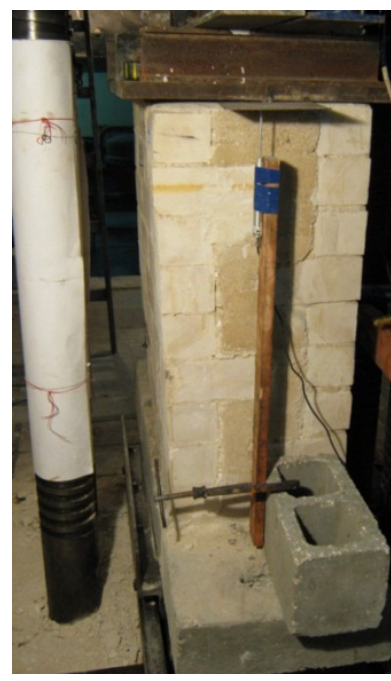

W12 during testing

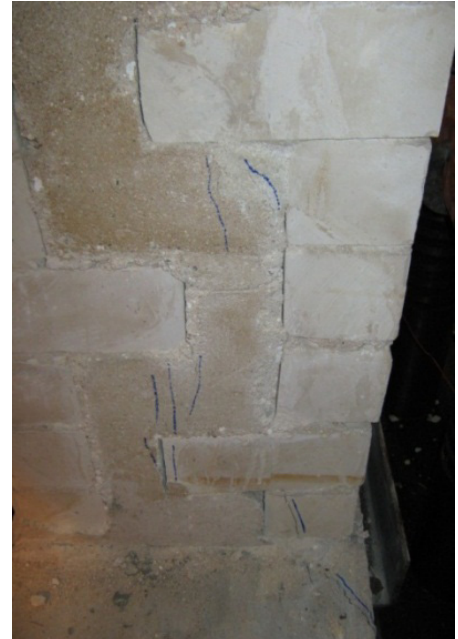

Crack initiation in W12

Figure 15: Stress-strain relationship of specimen W7 to failure.

\section{Analysis of experimental results}

The effect of the different parameters on the wall performance under increasing load up to failure is presented in this section. Those parameters include the mortar strength, the mortar thickness and the wall system. For fair comparison, since not all walls are of the same thickness and structure the analysis shall be based on the average compressive strength instead of the failure load. Figure 16 displays the failure stress of the tested twelve walls.

The existence of small amount of white cement (5\% of weight) in the lime mortar increases the mortar strength from $0.14 \mathrm{~N} / \mathrm{mm}^{2}$ to $0.6 \mathrm{~N} / \mathrm{mm}^{2}$. This results in significant increase in the strength of the walls as shown in Figure 17. This effect was evident for the different thicknesses of mortar joint. 


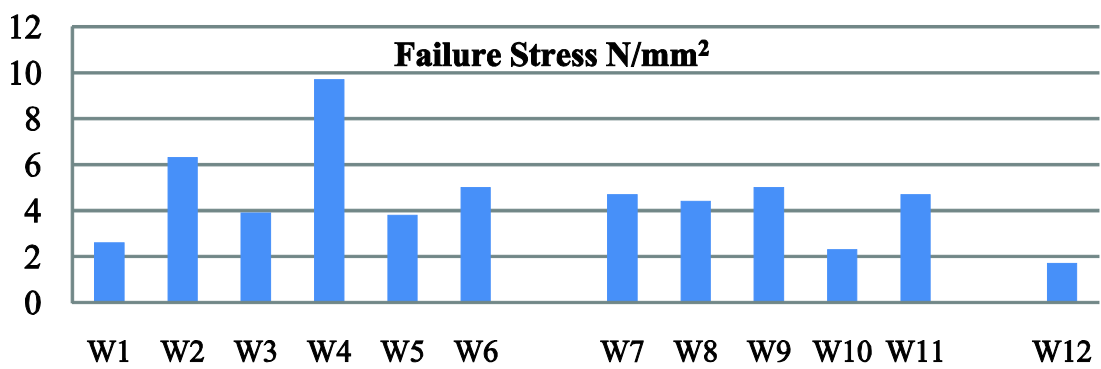

Figure 16: Comparison of the failure stress of the twelve tested walls.

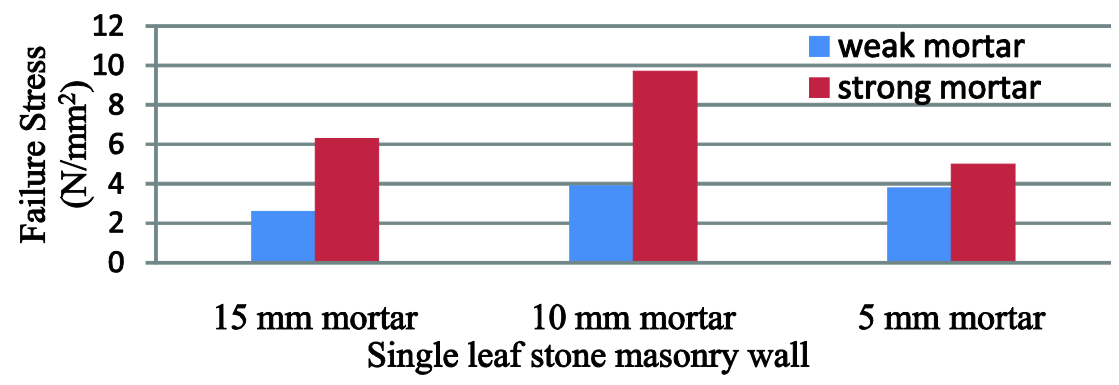

Figure 17: Effect of mortar strength on the strength of single leaf wall.

For single leaf walls W1 and W2 with thickness of mortar $15 \mathrm{~mm}$, the strength of wall W2 with strong mortar is higher than that of W1 with weak mortar by almost 2.5 folds (150\% increase). The same effect was observed for wall W3 and W4 of single walls with thickness of mortar $10 \mathrm{~mm}$. This effect was less pronounced in walls W5 and W6 with mortar thickness $5 \mathrm{~mm}$ where the increase was only $30 \%$. Similar behaviour was observed in the double lead walls.

Furthermore, the increase in the mortar strength results in significant increase in the overall stiffness of the wall. This effect is clearly shown in Figure 18 for wall W1 with weak mortar and wall W2 with strong mortar.

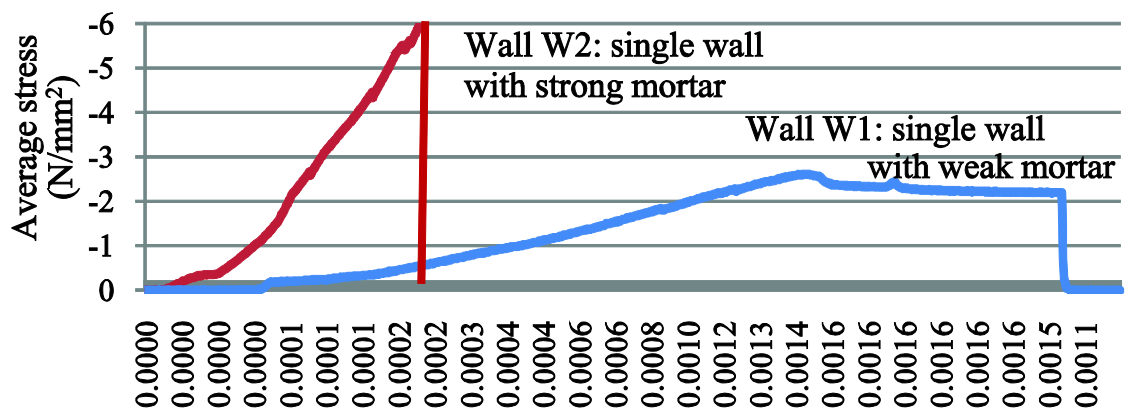

Average strains $(\mathrm{mm} / \mathrm{mm})$

Figure 18: Effect of mortar strength on the stiffness of the wall. 
The effect of mortars joint thickness on the overall strength of the masonry walls systems is displayed in Figure 19. It is observed that highest strength is attained at mortar thickness of $10 \mathrm{~mm}$. Increasing the mortar thickness to $15 \mathrm{~mm}$ slightly decreases the wall overall strength however improves the wall ductility as shown from the stress-strain curves of Figures 6-11, 13 and 14. Also, decreasing the mortar thickness to $5 \mathrm{~mm}$ decreases both the strength and ductility.

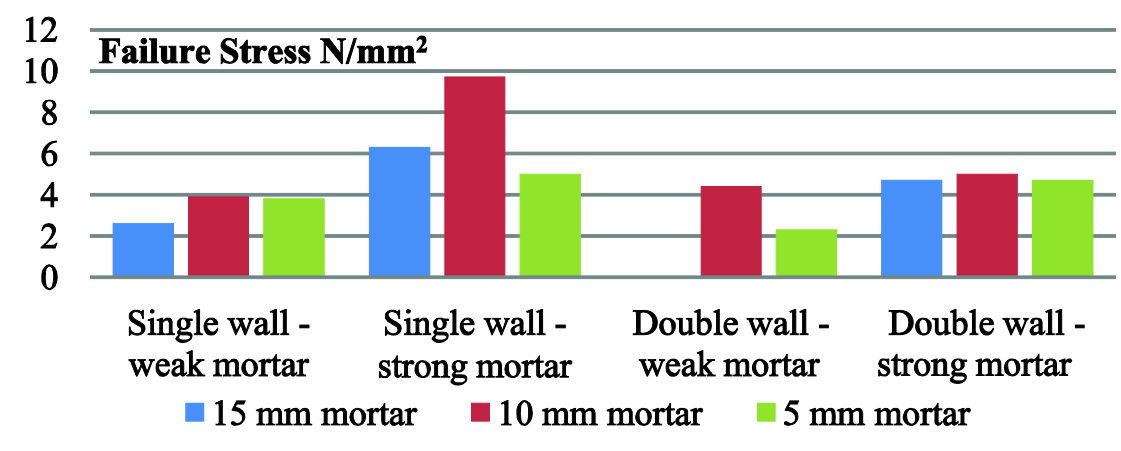

Figure 19: Effect of mortar joint thickness on the wall strength.

\section{Summary and conclusions}

Twelve limestone masonry walls models with lime based mortar were tested under increasing in-plane compressive load to failure. The effect of different parameter on the wall performance was evaluated in this study. Those parameters include: wall structure as single leaf, double leaf, and cavity wall with rubble infill; strength of lime based mortar where two types of mortar designated as weak and strong mortar are used; and the thickness of mortar joints where three thicknesses were tested $15 \mathrm{~mm}, 10 \mathrm{~mm}$, and $5 \mathrm{~mm}$. The mechanical properties of the natural stone units and mortars cubes were determined experimentally in this work.

The main modes of failure in almost all tested walls was splitting tension failure of stone blocks due to squeezing of mortar, followed by crushing of stones due to increasing compressive loads.

It is evident that, the strength of mortar in joints significantly affects the overall strength of the wall. Increasing mortar strength by adding white cement $(5 \%)$ increases the overall strength of the masonry wall by almost 2.5 folds.

Mortar is able to withstand higher compressive stresses in bed joints than stresses in cubes because of the confining restrains from the stone units. However, the lateral deformation of mortar is found to be greater than the stone blocks due to squeezing of mortar which causes lateral tension stresses in stone blocks and causes splitting of stones. Thus, the tensile strength of the stone blocks affects the overall compressive strength of masonry walls.

The behaviour of mortar joints in stone masonry walls under loading gives ductility to the wall and gives signs before collapse in terms of mortar squeeze 
and splitting cracks in stone blocks. It was found that walls built with thin mortar joints failed without enough warning compared with walls with thicker joints.

Thickness of mortar greatly affects the overall strength of the stone masonry wall. Increasing mortar thickness from $10 \mathrm{~mm}$ to $15 \mathrm{~mm}$ reduces the compressive strength by $29 \%$ for single walls, and $22 \%$ for double walls. Reducing mortar thickness from $10 \mathrm{~mm}$ to $5 \mathrm{~mm}$ reduces the compressive strength by $0.5 \%$ for single wall and $10 \%$ for double wall. In general, increasing mortar thickness reduces the wall strength but increases its ductility and the highest strength of the wall was achieved at mortar joint thickness of $10 \mathrm{~mm}$.

\section{References}

[1] Abdel-Mooty, M.N., Mourad, S.A., and Abdel-Gawad, A.A., Structural adequacy, damage assessment, and repair methodology of historical walls, Arab Conference for Strengthening and Rehabilitation of Structures, September 16-17, 1998, Cairo, Egypt, Vol. 2, pp. 1041-1057.

[2] Hayen R., Van Balen K., Van Gemert D., Schueremans L., The influence of the brick/mortar interaction on the mechanical behaviour of historic masonry, STREMAH VI Computer Methods in Structural Masonry, pp. 2224, 2003.

[3] Abdel-Mooty, M.N., and Abdo, S.M., Structural behaviour of natural stone masonry walls under vertical and lateral loads, International Conference on Future Vision and Challenges for Urban Development, Cairo, Egypt, 20-22 December 2004.

[4] Hayen, R., Schueremans, L., Van Balen, K. and Van Gemert, D., Triaxial testing of historic masonry, test set-up and first results, Structural Studies, repairs, and Maintenance of Historical Buildings, VII, Ed. C. A. BREBBIA, pp. 151-160 Southampton (UK): WIT Press, 2001.

[5] Valluzzi, M. R., Porto, D. A., and Modena, C., Behavior of multi-leaf stone masonry walls strengthened by different intervention techniques, Historical Constructions, P.B. Lourenco, P. Roca (Eds), Guimaraes, pp. 1023-1025, 2001.

[6] Bartoli, G., Casamaggi, C., Spinelli, P., Numerical modelling and analysis of monumental buildings: a case study, Memoria Presentata al Convegno CICOP “FIRENZE2000”, 5th International Congress on Restoration of Architectural Heritage, September 2000.

[7] Pina-Henriques, J.L., Lourenço, P.B., Binda, L., Anzani, A., (2004). Testing and modelling of multiple-leaf masonry walls under shear and compression, in Proc. 4th Int. Seminar on Structural Analysis of Historical Constructions, Padova, Italy, p. 299-310, 2004.

[8] Fahmy E., and Ghoneim T., Behavior of concrete block masonry prisms under axial compression", Canadian Journal of Civil Engineering, Vol.22, pp. 898-915, 1996.

[9] Abdel-Mooty, M., Khedr, S. and Mahfouz, T., Evaluation of lime mortars for repair of historic structures," 11th Int. Conf. on Structural Repairs and Maintenance of Heritage Architecture, 22-24 July, 2009, Tallinn, Estonia. 